\title{
Kebijakan Hukum Perbuatan Pelecehan Seksual (Catcalling) dalam Perspektif Hukum Pidana
}

\author{
Yuni Kartika, Andi Najemi \\ Fakultas Hukum, Universitas Jambi \\ Author's email correspondence: kartikayuni29960@gmail.com
}

\begin{abstract}
ABSTRAK
Artikel ini bertujuan untuk memahami dan menganalisis pengaturan tentang perbuatan catcalling dalam perspektif hukum pidana serta menganalisis pengaturan perbuatan pelecehan seksual verbal menurut pembaharuan hukum pidana. Penelitian ini merupakan penelitian hukum normatif. Hasil penelitian ini bahwa perbuatan (catcalling) berpotensi adanya tindak pidana yang telah memenuhi unsur-unsur dari tindak pidana, perbuatan ini dikategorikan sebagai perbuatan pelecehan seksual verbal dan dapat dikaji dari beberapa pasal di dalam KUHP, Undang-Undang tentang pornografi serta diperlukannya suatu kebijakan hukum terkait aturan khusus perbuatan catcalling untuk mencapai suatu kepastian hukum dan juga terpenuhinya suatu syarat-syarat kriminalisasi sehingga perbuatan catcalling bisa dibuat aturan secara khusus. Kesimpulannya yaitu perbuatan catcalling berpotensi suatu tindak pidana yang terjadi di ruang lingkup publik melalui unsur-unsur suatu tindak pidana, dampak perbuatan catcalling ini mengakibatkan terganggunya mental, psikologi, sampai pada tingkat kejiwaan dan untuk menentukan suatu kebijakan perlu memperhatikan moral, nilai dan asas yang terkadung di dalam masyarakat dan memperhatikan syaratsyarat kriminalisasi. Untuk mencapai suatu kepastian hukum perlunya kebijakan hukum mengenai aturan secara khusus terkait perbuatan catcalling serta adanya sanksi sosial bagi pelaku catcalling
\end{abstract}

\section{ARTICLE HISTORY}

Submission: 2020-04-21

Accepted: 2020-10-07

Publish: 2020-10-10

KEYWORDS: Catcalling; criminal law policy; verbal sexual harassment
Kata Kunci: Catcalling; kebijakan hukum pidana; pelecehan seksual verbal.

\section{ABSTRACT}

This article aims to understand and analyze the regulation of catcalling from the perspective of criminal law and to analyze the regulation of verbal sexual harassment according to the reform of the criminal law. This research is a normative legal research. The results of this study indicate that catcalling has the potential for a criminal act that has met the elements of a criminal act, this act is categorized as an act of verbal sexual harassment and can be reviewed from several articles in the Criminal Code, the Law on pornography and the need for a legal policy related to the special rules for catcalling acts to achieve legal certainty and also the fulfillment of a criminalization condition so that the catcalling act can be made specific rules. The conclusion is that catcalling is potentially a criminal act that occurs in the public sphere through the elements of a criminal act, the impact of this catcalling act causes mental and psychological disruption to the psychological level and to determine a policy it is necessary to pay attention to the morals, values and principles involved. in society and pay attention to the conditions for criminalization. To achieve legal certainty, it is necessary to have a legal policy regarding specific rules related to catcalling acts as well as the existence of social sanctions for catcallers. 


\section{A. PENDAHULUAN}

Artikel ini membahas tentang permasalahan sosial yang dianggap suatu hal yang wajar di kalangan masyarakat, namun memiliki dampak buruk bagi kalangan yang menjadi objek dari perbuatan tersebut. Perbuatan ini berpotensi adanya tindak pidana, namun tidak ada kepastian hukum padahal perbuatan ini merupakan kategori kejahatan yang melanggar norma kesusilaan dan termasuk pelecehan seksual verbal.

Pelecahan Seksual merupakan bentuk tingkah laku mengandung seksual yang tidak diinginkan oleh objeknya, permintaan untuk melakukan perbuatan seksual, baik secara lisan, atau fisik yang tempat kejadiannya bisa di ruang publik. Perbuatan dalam bentuk lisan maupun fisik kini sering terjadi di kalangan masyarakat khususnya bagi perempuan. Hal tersebut membuat perempuan tidak merasa aman, damai dan tentram. Apalagi perbuatan pelecehan seksual dilakukan di ruang publik akan lebih membuat korban merasa tidak aman dan nyaman saat berada di luar rumah. Padahal setiap orang berhak atas rasa aman dan tentram serta perlindungan terhadap ancaman ketakutan, hal ini diatur dalam Pasal 30 Undang-Undang Nomor 39 Tahun 1999 Tentang Hak Asasi Manusia.

Pelecehan seksual memiliki ruang lingkup yang sangat luas, berbagai bentuk dari lisan maupun tulisan, fisik dan non fisik, mulai dari adanya ungkapan verbal (komentar yang tidak senonoh, gurauan berbau seksual dan sebagainya) dalam bentuk fisik (mencolek, meraba, mengeus, memeluk dan sebagainya), mempertunjukan gambar porno/jorok, serangan dan paksaan yang tidak senonoh seperti, memaksa untuk mencium atau memeluk, mengancam akan menyulitkan si perempuan bisa menolak memberikan pelayanan seksual, hingga perkosaan ${ }^{1}$. Hal itu sering terjadi bahkan secara grafik adanya peningkatan untuk perbuatan pelecehan seksual.

Salah satunya di Indonesia, yang merupakan Negara darurat akan perbuatan pelecehan seksual yang membuat terancamnya masyarakat. Hal ini telah menjadi permasalahan global bagi masyarakat khususnya bagi kalangan perempuan. Pelecehan tersebut sering terjadi pada perempuan dengan pelecehan secara verbal maupun non verbal. Berbagai bentuk pelecehan yang dilakukan, perlakuan-perlakuan yang tidak pantas secara lisan maupun fisik menjadi masalah hingga mengganggu hak asasi manusia. Bahkan hal tersebut juga sering terjadi di muka umum baik dijalan, mall, angkutan umum, pasar bahkan di lingkungan masyarakat yang termasuk pelecehan verbal. Adanya perlakuan tersebut membuat korban terganggu dari segi kenyamanannya, terganggunya hak asasi korban.

Penegakan hak asasi manusia yang tidak tegas menyebabkan mudah munculnya perbuatan pidana. Seperti kekerasan seksual di ruang publik sulit untuk dipidana, karena tidak ada aturan yang secara tegas untuk mengatur hal tersebut. Salah satu perbuatan yang sering terjadi namun tidak ada tindak lanjut yang tegas ataupun aturan yang mengatur hal tersebut adalah perbuatan Catcalling. Dipergunakan istilah catcalling dalam tulisan ini karena istilah catcalling dipergunakan secara global diberbagai negara. Catcalling atau yang dapat diartikan sebagai pelecehan verbal merupakan melakukan suatu perbuatan sepeti melontarkan kata bersifat porno/seksual maupun perilaku genit, gatal, atau centil kepada orang lain yang menimbulkan rasa tidak nyaman dan juga berupa siulan dipanggil dengan sebutan "hay

1 Marcheyla Sumera, "Perbuatan Kekerasan/Pelecehan Terhadap Perempuan," Lex et Societatis, Vol. 1 No. 2, 2013, hlm. 43-44. 
cantik sini duduk di pangkuan abang”, "cewek main yuk, semalam berapa, jangan malumalu", "mau kemana neng, godain kita dong, sini abang antaerin", dilakukan oleh orang yang tidak dikenal, komentar yang tidak diinginkan, seperti "cantik sekali neng, body nya semok sekali", "jangan galak-galak nanti dicium ya!", diamati tubuhnya oleh orang asing hingga sampai pada perbuatan yang menimbulkan suatu bentuk rabaan yang tidak diharapkan yang menimbulkan rasa tidak aman ini dikategorikan sebagai street harassment ${ }^{2}$. Kekerasan seksual ringan berupa seksual secara Verbal seperti komentar verbal, gurauan, porno, siulan ejekan, dan secara non verbal seperti ekspresi wajah, gerakan tubuh ataupun perbuatan lainnya yang meminta perhatian seksual yang tidak dikehendaki korban bersifat melecehan dan atau menghina korban ${ }^{3}$.

Perbuatan catcalling ini tidak hanya sebatas suatu panggilan, siulan bahkan namun adanya batasan perbuatan catcalling yang benar-benar berpotensi adanya tindak pidana dan perlu pengaturan khusus seperti komentar-komentar seksual, mengomentari bentuk tubuh, berusaha menggoda perempuan dengan perkataan manis sampai kepada seksual serta melihatkan alat vital yang dilakukan secara berkelanjutan. Hal ini merupakan perbuatan yang memang mengganggu hak azasi seseorang yang merupakan kejahatan kesusilaan selalu dianggap biasa bagi kalangan masyarakat. Padahal perbuatan catcalling membuat seseorang merasa takut untuk keluar rumah, tidak merasaka aman, nyaman tentram akibat dari perbuatan tersebut sangat berpengaruh bagi seseorang dari segi psikologis, mental, dan pemenuhan hak asasi manusia dan realisasi sosial sehingga perlu adanya tindak lanjut dengan adanya aturan khusus. Namun sejatinya ketika hal tersebut terjadi hanya sedikit yang menanggapi dan bahkan tidak ditanggapi oleh para penegak hukum ketika dilaporkan sudah jelas itu merupakan kejahatan kesusilaan. Faktanya yang menjadi korban dari pelecehan verbal (catcalling) takut untuk melapor karena, kurangnya respon dari masyarakat bahkan penegak hukum serta belum ada suatu kepastian hukum. Biasanya yang menjadi korban dalam perbuatan catcalling ini adalah perempuan, namun bisa juga kaum laki-laki, serta kaum Gay yang memang menjadi objek catcalling itu sendiri. Dan juga yang paling sering menjadi korban perbuatan catcalling ini adalah kaum perempuan.

Berbagai masalah yang terjadi dalam penegakan hukum dibidang kesusilaan, permasalahan dari segi penafsiran yang tidak seragam membuat sulitnya dalam penetapan dasar hukum yang berkaitan dengan perbuatan tersebut sehingga adanya pergeseran norma-norma hukum dalam soal permasalahannya ${ }^{4}$. Menurut catatan tahunan Komisi Nasional Anti Kekerasan Terhadap Perempuan (Komnas Perempuan), di tahun 2017 terdapat 348.446 kasus kekerasan terhadap perempuan yang tercatat, $26 \%$ atau 3.528 kasus diantaranya terjadi diruang publik ${ }^{5}$. Dari data yang ada menurut Ketua Komnas Wanita Azriana Rambe Manalu (2017), data yang didapat kan oleh Komnas Perempuan sejak tahun 2010 sampai 2015 kekerasan terhadap perempuan

2 Ida Ayu Adnyaswari Dewi, “ Catcalling : Candaan, Pujian atau Pelecehan Seksual,” Jurnal Hukum Kenotariatan, Vol.4 No. 2, 2019, hlm. 199.

3 Eka Ayuningtyas,dkk, "Konsep Pencabulan Verbal dan Non Verbal dalam Hukum Pidana," Jurnal Education and Development Institut Pendidikan Tapanuli Selatan, Vol. 7 No. 3, 2019, hlm. 244.

4 Asrianto Zainal, "Kejahatan Kesusilaan dan Pelecehan Seksual ditinjau Dari Kebijakan Hukum Pidana,"Vol. 7 No.1, 2014,hlm. 139.

5 Marcheyla Sumera.,Op.Cit., hlm. 200. 
hingga mencapai anmengalami peningkatan memperoleh angka yang sangat tinggi yaitu sebanyak 321.752, walaupun pada tahun 2016 angka kekerasan terhadap perempuan mengalami penurunan menjadi 259.150, jika dibandingkan dengan tahun 2010-2012 (106.103-216.156) angka pada tahun 2016 tetap tergolong tinggi6.

Perbuatan yang tergolongan perilaku kekerasan kepada wanita adalah pelecehan seksual di jalan (sexual street harassment) telah menjadi masalah sosial, menurut riset yang diadakan oleh Hollaback.org ada $71 \%$ wanita di dunia pernah mengalami street harassment sejak usia puber (11-17 tahun) hingga sampai pada masa dewasa, dan lebih dari 50\% diantaranya termasuk pelecehan fisik dan sisanya adalah pelecehan secara verbal dan visual7. Menurut survey yang diadakan CCN Indonesia (2016) dari 25.213 responden baik dari kota maupun kabupaten, sebanyak 58\% pernah mengalami pelecehan dalam bentuk verbal ${ }^{8}$. Pelecehan yang terjadi di ruang publik biasanya perbuatan catcalling untuk mendapatkan perhatian lebih dari perempuan tersebut dan berharap akan direspon. Padahal akan menimbulkan ketidaknyamanan bagi perempuan dan menimbulkan rasa takut yang berlebihan.

Pelecehan seksual verbal ini tidak hanya terjadi di Indonesia melainkan di Negara lainnya. Pelecehan seksual verbal oleh beberapa Negara, seperti Perancis, Argentina, Portugal, Belgia dan Peru telah ditanggapi secara serius karena berdampak besar pada kehidupan sosial manusia dan psikologis korban. Negara tersebut menerapkan bukan hanya sanksi pidana tetapi juga sanksi denda kepada pelaku yang melakukan catcalling atau pelecehan seksual verbal ${ }^{9}$. Pelecehan seksual verbal ini semakin meningkat dikalangan perempuan dan cendrung dibiarkan dan tidak adanya kepastian hukum bagi korban. Catcalling dan street harassment sendiri merupakan fenomena yang jarang sekali diteliti, karena hal ini dianggap suatu perbuatan yang biasa di lingkungan masyarakat, padahal apabila diteliti lebih lanjut banyak korban merasakan ketidaknyamanan bahkan dampak yang ditimbulkan berpengaruh bagi korban. Oleh karena itu isu ini sering kali dianggap remeh, dianggap sesuatu yang sangat di maklumi secara cultural bahkan dinormalisasi. Hal tersebut bukanlah suatu yang wajar bagi objek catcalling, sehingga ini merupakan suatu perbuatan pidana dan harus dipertanggungjawabkan. adapun dampak dari catcalling memicu terganggunya psikologis bagi perempuan yang mengakibatkan terjadinya kekerasan psikologis. Kekerasan psikologis/ emosional adalah perbuatan yang mengakibatkan ketakutan, hilangnya rasa percaya diri, hilangnya kemampuan untuk bertindak, rasa tidak berdaya dan atau penderitaan psikis berat pada seseorang10. Dan juga mengakibatkan timbulnya trauma bagi korban yang terkena catcalling bahkan perbuatan ini bisa terus terjadi dan tidak mendapatkan tanggapan dari masyarakat maupun penegak hukum.

Pada kasus yang dialami seorang dokter bernama Falla Adinda mengalami catcalling ditempat kerjanya. Pada bulan September 2017, bukan pertama kalinya ia mengalami catcalling. Ia digoda dengan kata-kata yang pantas serta membuat kkorban

6 Joy Gloria dkk."Perancangan Kampanye osial "JAGOAN," (Program Studi Desain Komunikasi Visual,Fakultas Seni dan Desain Universitan Kristen Petra), hlm.1.

7 Marcheyla Sumera. Op.Cit., hlm. 2.

8 Ida Ayu Adnyaswari Dewi. Op.Cit., hlm. 200.

9 Ibid.

10 Andi Najemi, Pahlefi, " IbM Kelompok Pkk Desa Pematang Pulai dan Kel. Sengeti Tentang Hukum Gender Tentang Mengantisipasi KDRT," Jurnal Pengabdian Pada Masyarakat, Vol. 30 No. 1, 2015, hlm. 51. 
merasa risih dengan perkataan catcaller., biasanya ketika ia mendapatkan catcalling ia langsung mendatangi dan berbicara kepada sipelaku, namun pada saat itu ia langsung pergi karena tidak tahan lagi dengan tindakan pelaku dan mendiamkan si pelaku. Falla pun melaporkan kejadian tersebut kejadian tersebut kepada polisi dan meminta polisi untuk menindak lanjuti pelaku catcalling, alih-alih Falla diperlakukan dengan baik dan dibantu kemudian Falla diremehkan dan diperintahkan untuk pergi. Setelah Falla mendapatkan penolakan dari polisi pertama, kemudian falla bertemu polisi kedua yang menanggapi dan mendengar kronologis kejadian tersebut. Dan pada akhirnya polisi mendamaikan dengan meminta kepada sipelaku untuk tidak mengulangi perbuatan catcalling lagi.

Kemudian kasus yang terjadi pada 6 September 2019 malam, Polres Metro Bekasi berhasil menangkap pelaku catcalling di lampu merah Simpang Pekayonan Revo Town Bekasi. Pelaku ditangkap setelah ada viral tentang kisah seorang wanita sedang mengendarai sepeda motor yang menjadi korban pelecehan seksual verbal. Korban merasa risih dengan perkataan pelaku (catcaller) yang saat itu sama-sama berhenti di lampu merah dan kemudian pelaku berlanjut mengikuti korban. Akhirnya korban berani merekam wajah pelaku dengan bukti video yang diunggahnya ke akun sosmed.

Perbuatan catcalling yang semakin sering terjadi, akan mengakibatkan dampak buruk bagi si korban. Namun masih banyak korban yang tidak berani untuk melaporkan dan memilih untuk diam. Tidak banyak pula yang berani memberikan bantuan ataupun pembelaan terhadap korban catcalling karena takut akan menjadi keributan. Seiring dengan kemajuan jaman dan perkembangan teknologi informasi maka permasalahan terkait street harassment khususnnya catcalling maka semakin marak pula perbuatan catcalling bermunculan. Oleh karena itu perlu dikaji bagaimana pengaturan catcalling itu sendiri dalam sistem hukum Indonesia dan kebijakan hukum dalam pembaharuan pengaturan perbuatan tindak pidana yang awalnya merupakan perbuatan biasa sampai dikategorikan perbuatan pidana.

Jika dilihat dari prespektif hukum pidana bahwa pelecehan seksual verbal (catcalling) adanya penggabungan terhadap aturan yang mengatur perbuatan tersebut. Seperti yang diatur dalam Pasal 281 Ayat (2) Pasal 289, Kitab Undang-Undang Hukum Pidana, Pasal 8, Pasal 9, Pasal 34, Pasal 35 Undang-Undang Nomor 44 Tahun 2008 Tentang Pornografi digunakan untuk penyelesaian perbuatan catcalling (pelecehan seksual verbal) terhadap perempuan di Indonesia yang selanjutnya dikutip sebagai berikut:

Pasal 281 Ayat (2)

"Barang siapa dengan sengaja dan di depan orang lain yang ada di situ bertentangan dengan kehendaknya melanggar kesusilaan".

Pasal 289

"Barang siapa dengan kekerasan memaksa seseorang untuk melakukan atau membiarkan dilakukan perbuatan cabul, diancam karena melakukan perbuatan yang menyerang kehormatan kesusilaan, dengan pidana penjara paling lama sembilan tahun".

Pasal 8 
"Setiap orang dilarang dengan sengaja atau atas persetujuan dirinya menjadi objek atau model yang mengandung muatan pornografi"

Pasal 9

"Setiap orang dilarang menjadikan orang lain sebagai objek atau model yang mengandung muatan pornografi."

Pasal 34

"Setiap orang yang dengan sengaja atau atas persetujuan dirinya menjadi objek atau model yang mengandung muatan pornografi sebagaimana dimaksud dalam Pasal 8 dipidana dengan pidana penjara paling lama 10 (sepuluh) tahun dan/atau pidana denda paling banyak Rp.5.000.000.000,00 (lima miliar rupiah)."

Pasal 35

"Setiap orang yang menjadikan orang lain sebagai objek atau model yang mengandung muatan pornografi sebagaimana dimaksud dalam Pasal 9 dipidana dengan pidana penjara paling singkat 1 (satu) tahun dan paling lama 12 (dua belas) tahun dan/atau pidana denda paling sedikit Rp.500.000.000,00 (lima ratus juta rupiah) dan paling banyak Rp.6.000.000.000,00 (enam miliar rupiah)."

Penjelasan pasal di atas sudah jelas bahwa perbuatan catcalling merupakan suatu perbuatan pidana yang memerlukan pengaturan khusus mengenai catcalling. Dan juga belum ada penelitian yang secara spesifik mengungkap perbuatan catcalling ini sebagai seuatu perbuatan pidana, bahkan ada yang berpendapat perbuatan ini adalah bentuk hal yang wajar. Berbeda dengan Negara lain yang telah mengatur bahwa catcalling merupakan suatu perbuatan pidana. Kemudian perbuatan catcalling dikategorikan sebagai perbuatan yang melanggar kesusilaan serta mengakibatkan dampak yang besar bagi korban. Pelaku dari perbuatan catcalling (pelecehan seksual verbal) disebut sebagai catcaller yang harus dipidana karena telah melanggar hak asasi seseorang serta perbuatannya tidak dikehendaki oleh yang menjadi korban.

\section{B. METODE PENELITIAN}

Artikel ini menggunakan metode yuridis normative, dimana penelitian ini berangkat dari adanya isu hukum yang dilakukan untuk menghasilkan argumentasi, teori, atau konsep baru sebagai preskripsi dalam menghadapi masalah yang dihadapi dan diperoleh dari studi kepustakaan, dengan menganalisis suatu permasalahan hukum melalui peratuaran perundang-undangan, literatur-literatur, dan bahan-bahan referensi lainnya. Mengkaji perbuatan catcalling dari perspektif hukum pidana yaitu Pasal 281 Ayat (2) Pasal 289, Kitab Undang-Undang Hukum Pidana, Pasal 8, Pasal 9, Pasal 34, Pasal 35 Undang-Undang Nomor 44 Tahun 2008 Tentang Pornografi. Kemudian dalam segi pembaharuan hukum harus mengkaji dari segi kebijakan hukum yang memperhatikan moral, nilai, asas serta syarat-syarat kriminalisasi.

\section{PEMBAHASAN}

\section{Pengaturan Perbuatan Pelecehan Seksual Verbal (Catcalling) dalam} Perspektif Hukum Pidana

Pelecehan seksual adalah suatu kenyataan yang sering terjadi di lingkungan masyarakat dengan berbagai bentuk hingga sampai pada perbuatan pemerkosaan. 
Salah satunya pelecehan seksual verbal (catcalling). Berawal dari hal-hal kecil yang dianggap perbuatan biasa oleh masyarakat, sebenarnya menimbulkan dampak besar dan menjadi masalah sosial di lingkungan masyarakat. Catcalling ini telah menjadi masalah sosial yang dianggap hal biasa di kalangan publik. Biasanya catcalling ini terjadi di jalan, pasar, angkutan umum, bahkan di mall. Padahal catcalling sudah menjadi perbuatan yang tidak bisa dianggap biasa, dan telah dianggap sebagai "hantu" bagi kalangan perempuan.

Perbuatan catcalling ini bisa sampai pada perbuatan pemerkosaan. Padahal perempuan yang menjadi korban catcalling ini sudah berusaha untuk tidak merespon perbuatan dari si pelaku catcalling (catcaller). Namun nyatanya penolakan tersebut membuat catcaller merasa penasaran dan melakukan kembali jenis catcalling lainnya yang kemudian membuat perempuan merasa dilecehkan dan merasa hak asasinya terganggu. Bahaya catcalling lebih cendrung memicu dari segi psikologis korban dan berpengaruh pada emosi korban tersebut, seperti ada rasa takut dalam diri korban, lebih cendrung merasa tidak nyaman, tidak mendapat keamanan ketika berada di luar rumah, perasaan malu akibat dari perbuatan catcalling ${ }^{11}$. Dengan demikian perbuatan catcalling ini bisa menjadi tindak pidana kesusilaan yang terjadi di ruang publik.

Jika memfokuskan pada kata perbuatan yang tidak diinginkan, dapat dikategorikan bahwa ini merupakan suatu delik aduan, pidana yang berpotensi sebagai perbuatan pidana. Perbuatan pidana merupakan suatu proses perbuatan yang dilarang karena melanggar atauran hukum dan memiliki ancaman sanksi terhadap orang yang melanggar aturan tersebut, larangan yang ditunjukan kepada perbutannya dan sanksi ditunjukan orang yang menimbulkan perbuatan ${ }^{12}$. Di dalam istilah perbuatan pidana ada beberapa istilah lain seperti, peristiwa pidana dan tindak pidana.

Jika dilihat dari penjabaran unsur-unsur suatu tindak pidana yang dikemukan Simon terdapat 5 (lima) unsur perbuatan tersebut dapat dikatakan sebagai perbuatan pidana. Adapun unsur-unsur yang dikemukan oleh Simon antara lain yaitu: adanya suatu perbuatan yang dilakukan oleh manusia, perbuatan tersebut diancam dengan pidana, sifat dari perbuatan itu merupakan melawan hukum, dilakukan dengan kesalahan, dan dapat dipertanggungjawabkan ${ }^{13}$. Maka berdasarkan penjelasan unsur di atas, adapun unsur-unsur dari catcalling adalah sebagai berikut:

a. Adanya suatu perbuatan yang dilakukan oleh manusia

Perbuatan catcalling memenuhi unsur perbuatan manusia. Hal ini dapat dilihat dari suatu perbuatan yang dilakukan oleh catcaller terhadap korbannya. Perbuatan yang dilakukan oleh catcaller adalah melontarkan kata-kata/komentar porno atau perilaku-perilaku yang membuat orang lain yang menjadi korban merasa risih. Misalnya, bersiul dengan memanyunkan bibir serta mengkedipkan mata.

b. Perbuatan diancam dengan pidana

Perbuatan catalling ini termasuk perbuatan pelecehan seksual verbal yang terjadi di ruang pulbik, dikategorikan sebagai tindak pidana kesusilaan karena termasuk perbuatan asusila dan mengandung unsur pornografi.

11 Ida Ayu Adnyaswari Dewi, Op.Cit., hlm. 206.

12 Moeljatno, Asas-Asas Hukum Pidana, Rineka Cipta, Jakarta, 2010,hlm.59.

13 Andi Hamzah, loc. Cit. 
Sehingga perbuatan ini bukan lagi perbuatan yang biasa dan kemudian tidak ada penanganan lebih lanjut.

c. Perbuatan tersebut berisifat melawan hukum

Catcalling ini dapat dikatakan perbuatan melawan hukum karena telah mengganggu kenyamanan, keamanan, bagi orang lain serta mengganggu hak asasi orang lain. Dimana mengganggu hak asasi orang lain merupakan perbuatan melanggar hukum.

d. Dilakukan dengan kesalahan

Adapun unsur-unsur dari kesalahan tersebut diantaranya, kapasitas dari diri pelaku (catcaller) kejahatan tersebut untuk mampu bertanggung jawab atas perbuatan yang dilakukannya. Kemudian adanya hubungan batin antara si pelaku dengan perbuatan yang dilakukannya. Dalam suatu perbuatan adanya bentuk kesengajaan dan kealpaan yang tidak ada alas an penghapus kesalahan yang berupa alasan pembenar. Maka perbuatan yang dilakukan oleh si pelaku merupakan bentuk perbuatan dalam bentuk kesengajaan.

e. Dapat dipertanggungjawabkan oleh pelaku

Suatu pertanggungjawaban dari catcaller berkaitan dengan kesalahannya. Kesalahan sebagai suatu unsur pertanggungjawaban pidana. Orang yang mampu bertanggung jawab apabila tidak ada alasan pemaaf dan alasan pembenar atas perbuatan yang dilakukan.

Pengertian pelecehan seksual di atas mengandung unsur yang sangat penting yaitu adanya rasa tidak ingin serta penolakan dari si korban dengan berbagai bentuk seperti, pelecehan fisik, lisan, isyarat, pelecehan dalam bentuk tulis atau gambar, pelecehan dari segi psikologis atau emosional. Pelecehan seksual verbal (catcalling) dapat dikategorikan sebagai tindak pidana yang telah memenuhi unsur-unsur, asas dalam hukum pidana, serta nilai-nilai yang terkadung di dalam masyarakat. Perbuatan catcalling membuat perempuan yang menjadi korban catcalling merasa tidak aman, nyaman, serta marasa terancam ketika berada di luar rumah. Hal tersebut sudah sepatutnya menjadi perhatian dan harus ditindak lanjuti untuk mencegah perbuatan yang menimbulkan dampak besar. Dari dampak tersebut, sudah sepatutnya perbuatan catcalling ada pengaturan yang jelas serta penegakan hukum terhadap penanganan perbuatan catcalling. Dalam kehidupan sehari-hari banyak perempuan yang menjadi korban catcalling yang merupakan pelecehan seksual verbal.

Sejauh ini, dalam perkembangan hukum di Indonesia, belum ada peraturan secara khusus mengenai perbuatan catcalling ini. Padahal catcalling telah menjadi gejala sosial yang meresahkan perempuan yang sering menjadi korban, dalam penegakan hukumnya pun belum adanya kejelasan mengenai dasar hukum serta penanganan yang tegas dalam penyelesaian perkaranya. Kemudian terdapatnya kekosongan norma hukum atas perbuatan catcalling yang semakin meningkat. Hal ini dapat dilihat dari perspektif hukum pidana melalui penggabungan beberapa pasal yang terdapat dalam KUHP dan Undang-Undang tentang pornografi untuk menyelesaikan perkara catcalling. Ada beberapa pasal yang digunakan dalam penyelesaian perkara tindak pidana catcalling diantaranya, Pasal 281 Ayat (2) KUHP, Pasal 8, Pasal 9, Pasal 34, dan Pasal 35 Undang-Undang Nomor 44 Tahun 2008 Tentang Pornografi.

Pasal 281 KUHP ayat (2) menerangkan bahwa apabila seseorang dengan sengaja didepan orang lain yang ada di situ diluar kesedian orang tersebut melakukan perbuatan asusila, maka dapat dipidana denda (Lihat Pasal 281 Ayat 1). Kesusilan yang 
dimaksud dalam pasal ini memiliki arti yang sama dengan perbuatan yang terjadi di ruang publik. Hal ini memberikan suatu pandangan mengenai perlindungan bagi orang-orang yang perlu perlindungan terhadap perbuatan asusila baik dari kata-kata yang dilontarkan sampai pada perbuatan yang merusak kesusilaan.

Adapun rumusun asli dari pasal 281 ini berbunyi sebagai berikut:

Met gevangenisstraf van ten hoogste twee jaren en acht maanden of geldboete van ten hoogste vier duizend en vijf honder gulden wordt gestraf:

1. Hij die opzettelijk openbaarheid schendt;

2. Hij die opzettelijk de eerbaarheid schendt, waardbij een ander zijns ondanks tegenwoordig is ${ }^{14}$.

Unsur-unsur tersebut diterjemahkan kedalam bahasa Indonesia sebagai berikut: Dipidana dengan pidana penjara selama-lamanya dua tahun dan delapan bulan atau dengan pidana denda setinggi-tingginya empat ribu lima ratus rupiah:

1. Barangsiapa dengan sengaja di depan umum merusak kesusilaan;

2. Barang siapa dengan sengaja merusak kesusilaan di depan orang lain yang kehadirannya di situ bukanlah atas kemauannya sendiri.

Pada perumusan unsur di atas terdapat unsur dengan sengaja, dilihat dari perbuatan catcalling ini terdapat unsur sengaja yang dilakukan oleh catcaller yang perbuatannya dapat dibuktikan. Penggunaan Undang-Undang tentang pornografi dapat digunakan untuk menyelesaikan perkara catcalling tersebut. Jika dilihat pada Pasal 1 Angka 1 Ketentuan Umum menyatakan bahwa pornografi adalah gambar, sketsa, ilustrasi, foto, tulisan, suara, bunyi, gambar bergerak, animasi, kartun, percakapan, gerak tubuh, atau bentuk pesan lainnya melalui berbagai bentuk media komunikasi dan/atau pertunjukan di muka umum, yang memuat kecabulan atau eksploitasi seksual yang melanggar norma kesusilaan dalam masyarakat. Sudah jelas bahwa perbuatan catcalling ini memenuhi unsur-unsur dari dari penjelasan pasal tersebut. Pengertian dari pornografi mengandung makna bahwa catcalling dapat dikatakan sebagai suatu hal yang memuat pornografi, karena telah memenuhi unsur dari Pasal 1 angka 1 salah satunya memenuhi unsur, bunyi, suara, dan gerak tubuh yang bersifat seksual. Itulah yang menjadi dasar dalam penjatuhan pidana bagi perbuatan catcalling.

Pada Pasal 8 Undang-Undang Tentang Pornografi secara garis besar menyatakan bahwa seseorang dilarang menjadikan orang lain sebagai objek atau model dari perbuatan si pelaku yang kemudian mengandung unsur pornografi walaupun atas persetujuannya (Lihat Pasal 8 Undang-Undang Nomor 44 Tahun 2008). Sudah jelas bahwa yang menjadi objek dari perbuatan catcalling yaitu kebanyakan perempuan melalui pujian-pujian bernuansa seksual serta komentar-komentar yang membuat korban merasa terganggu.

Penjelasan dari Pasal 8 ini berkaitan dengan penjelasan pada Pasal 34 UndangUndang Tentang Pornografi yang menyatakan bahwa:

"Setiap orang yang dengan sengaja atau atas persetujuan dirinya menjadi objek atau model yang mengandung muatan pornografi sebagaimana dimaksud dalam Pasal 8 dipidana dengan pidana penjara paling lama 10 (sepuluh) tahun dan/atau pidana denda paling banyak Rp5.000.000.000,00 (lima miliar rupiah)".

14 P.A.F Lamintang dan Theo Lamintang, Op.Cit, hlm. 2. 
Objek dalam unsur pasal tersebut merupakan objek yang dijadikan laki-laki sebagai perbuatan catcalling yang dilakukan. Pada umumnya yang menjadi objek catcalling ini biasanya perempuan yang tidak hanya dengan pakaian yang terbuka, tetapi perempuan yang mengenakan pakaian tertutup juga menjadi objek catcalling. Berbeda dengan Pasal 9 Undang-Undang Tentang Pornografi terdapat unsur tanpa persetujuan dari objek tersebut (Lihat penjelasan Pasal 9 ) yang berkaitan dengan Pasal 35 yang menyatakan bahwa:

"Setiap orang yang menjadikan orang lain sebagai objek atau model yang mengandung muatan pornografi sebagaimana dimaksud dalam Pasal 9 dipidana dengan pidana penjara laing singkat 1 (satu) tahun dan paling lama 12 (dua belas) tahun dan/atau pidana denda paling sedikit Rp500.000.000,00 (lima ratus juta rupiah) dan paling banyak Rp6.000.000.000,00 (enam miliar rupiah)".

Pasal inilah yang bisa dijadikan dasar dari perbuatan catcalling. Dari perumusan pasal tersebut menjadi tonggak dalam penyelasaian perbuatan catcalling, namun demikian belum bisa menjamin kepastian hukumnya. Maka dari itu penulis menginkan perlunya ada aturan khusus yang cendrung memicu bahaya dari akibat perbuatan catcalling. Namun tidak hanya dikaitkan dengan unsur pasal seperti dijelaskan di atas, melaikan dikaitkan dengan asas-asas hukum pidana yang dapat menentukan apakah perbuatan tersebut merupakan suatu perbuatan pidana yang diperlukan aturan khusus. Ada beberapa asas yang bisa dijadikan dasar dari suatu tindak pidana catcalling.

Asas Gen Straf Zander Schuld yang artinya tiada pidana tanpa kesalahan. Suatu kesalahan yang dilakukan oleh pelaku dengan bentuk sengaja dapat dikategorikan sebagai suatu tindak pidana. Perkembangan dari perbuatan catcalling semakin meningkat dikalangan masyarakat, ada beberapa yang berpendapat bahwa perbuatan catcalling ini merupakan hal yang biasa terjadi yang tidak patut dipermasalahkan, namun hal ini adalah suatu yang serius bagi korban yang pernah mengalami catcalling ini. Kemudian ada pula yang memandang bahwa catcalling bukanlah suatu perbuatan yang harus dipidana bahkan bukan merupakan suatu perbuatan pelecehan seksual verbal, melaikan hanya berupa candaan dari si catcaller.

Bertolak belakang dengan kenyataan yang ada, terdapat beberapa gerakangerakan atau suatu komunitas anti catcalling bermunculan di dunian dan banyak pula korban yang bercerita berbagi pengalamannya mengenai perbuatan catcalling, baik di dunia nyata ataupun media social. Seperti dibuatnya akun instagram dearcatcaller, mempublikasi semua permasalahan-permasalahan yang pernah dialami korban. Hasil survei melalui akun instagram dearcatcaller membuktikan bentuk pelecehan seksual diruang publik yang paling sering dialami korban antara lain 60\% komentar atas tubuh, siulan, diklakson, suara kecupan/ciuman, komentar rasis/seksis, komentar seksual, pujian-pujian, dan didekati terus oleh si catcaller (verbal) ${ }^{15}$. Kemudian data lainnya yaitu, pada bulan april 2019 terdapat 92\% (138 ) orang koresponden yang mengalami kejadian catcalling dan menurut riset yang diadakan oleh Hollaback.org 71 $\%$ wanita didunia pernah mengalami street harassment sejak usia puber (11-17 tahun), dan lebih dari 50\% diantaranya termasuk pelecehan fisik dan sisanya adalah pelecehan secara verbal dan visual ${ }^{16}$. Menurut survey yang diadakan CCN Indonesia (2016) dari

15 http://www.instagram.com/p/BmSum7yj8Bc/?igshid=1w63vtn4n2hf5, diakses Pukul 21;46

16 Marcheyla Sumera, loc. Cit. 
25.213 responden baik dari kota maupun kabupaten, sebanyak 58\% pernah mengalami pelecehan dalam bentuk verbal ${ }^{17}$. Dari data tersebut sudah jelas bahwa sudah sepatutnya pemerintah membuka mata terhadap gejala sosial yang menimbulkan dampak besar terhadap korban dari perbuatan catcalling.

Adanya suatu tindakan pemerintah dalam menyikapi perbuatan catcalling melalui kebijakan hukum kedepannya untuk memberikan perlindungan bagi korban yang menghapus rasa malu akibat dari stigmatisasi masyarakat, memulihkan mental psikologis korban. Sehingga perlu adanya peran pemerintah untuk mengambil kebijakan dan tidak menormalisasi perbuatan tersebut. Dengan demikian perbuatan pelecehan seksual verbal (catcalling) merupakan suatu tindak pidana yang telah memenuhi unsur-unsur dari suatu tindak pidana. Adanya suatu kesalahan dengan kesengajaan yang tidak ada alasan pembenar dan pemaaf dari suatu perbuatan. Perbuatan catcalling memiliki unsur penting dalam konsep pelecehan seksual verbal. Unsur dari perbuatan pelecehan seksual verbal (catcalling) adanya suatu ketidakinginan atau penolakan dari objek catcalling pada suatu bentuk perbuatan seperti, perhatian, komentar, siulan dan jenis catcalling lainnya. Sehingga bisa dikatakan bahwa perbuatan tersebut merupakan hal yang wajar dikalangan masyarakat, namun apabila terdapat penolakan, tidak dikehendaki oleh objek yang mennjadi korban maka perbuatan tersebut bisa dikategorikan sebagai perbuatan pelecehan seksua secara verbal. Yang kemudian harus ada peran pemerintah dalam menanggapi perbuatan yang tersebut.

\section{Pengaturan Pebuatan Pelecehan Seksual Verbal (Catcalling) Terhadap Pembaharuan Hukum Pidana Di Indonesia}

Dasar hukum dalam perbuatan pelecehan seksual verbal (catcalling) dalam perspektif hukum pidana bisa dilihat dari beberapa pasal yang berkaitan dengan pelecehan seksual verbal. Pasal tersebut yakni Pasal 281 Ayat (2) KUHP, Pasal 8, Pasal 9, Pasal 34, Pasal 35 Undang-Undang Tentang Pornografi. Ada hal yang mendasar mengapa digunakannya Undang-Undang Pornografi sebagai dasar hukum dalam perbuatan catcalling, yaitu dilihat dari pengertian Pornografi yang termuat di dalam Pasal 1 Angka 1 Ketentuan Umum Undang-Undang Nomor 44 Tahun 2008 Tentang Pornografi. Pada dasarnya, pengenaan pasal-pasal diatas tidak lah cukup menjamin mengenai kepastian hukumnya. Perlulah aturan-aturan khusus yang mengatur perbuatan catcalling itu sendiri. Di samping itu tidak ada lagi anggapan dari masyarakat maupun pemerintah untuk tetap menormalisasi perbuatan tersebut sebagai perbuatan yang wajar, melainkan merupakan suatu perbuatan pidana yang perlu pengaturan lebih lanjut untuk mencapai suatu kepastian hukum dalam penegakan hukumnya. Sehingga yang menjadi korban dalam perbuatan catcalling memiliki keberanian dalam melaporkan ataupun mengungkap kejadian yang dialaminya.

Salah satu yang menjadi alasan korban memilih untuk diam dalam menyikapi perbuatan catcalling ini, karena kurangnya respon yang dari aparat penegak hukum serta belum ada aturan yang khusus mengenai perbuatan catcalling tersebut. Maka dari itu, perbuatan catcalling yang telah menjadi gejala sosial namun tidak ada satupun yang bisa diproses. Berbeda dengan Negara lain yang telah menjadikan perbuatan

17 Ida Ayu Adnyaswari Dewi, loc. Cit. 
catcalling sebagai suatu tindak pidana. Bahkan telah dibuat aturan khusus dengan pidana penjara dan denda. Kemudian ada beberap komunitas yang telah dibuat sebagi komunitas anti catcalling, karena telah pekanya pemerintah terhadap perbuatan tersebut yang sejatinya telah mengancam perempuan ketika berada di luar rumah.

Di Indonesia ini kasus catcalling masih kurang dianggap serius oleh pemerintah, sehingga belum ada aturan hukum yang mengatur perbuatan dalam ruang lingkup pelecehan seksual verbal. Padahal kasus ini berdampak besar bagi yang menjadi korban catcalling. Catcalling yang berada pada suatu tindakan pelecehan seksual verbal yang belum termasuk perbuatan keji dan belum ada aturan khusus yang mengatur perbuatan itu. Di dalam KUHP pun hanya mengatur perbuatan cabul yang diatur pada Pasal 289-296 dengan artian perbuatan yang mangandung kesusilaan, keji dalam nafsu birahi, dan juga terdapatnya unsur paksaan pada pasal tersebut. Kemudian pada Pasal 281 KUHP pun mengatur pula mengenai perbuatan melanggar kesusilaan dan kesopanan, namun mengenai perbuatan pelecehan seksual belum ada batasan dan hukuman tindakan ini.

Perbuatan catcalling yang telah menjadi gejala sosial menjadikan sebagian masyarakat sadar akan hal ini yang membuat sebagian orang membuat suatu komunitas untuk mencegah terjadinya perbuatan pelecehan seksual di ruang publik seperti catcalling. Komunitas itu seperti, hollaback Jakarta, Mari Jeung Rebut, dan Lentera ID. Dari beberapa komunitas tersebut, telah melakukan survei, namun belum sepenuhnya berhasil. Menurut survei dari hollaback dan Lintera Indonesia 2019, masih banyak perempuan yang memberikan keluhan akan perbuatan catcalling. Yang menjadi alasan pelaku catcalling masih terus berkembang, karena belum ada undangundang secara spesifik yang mengatur perbuatan ini. Catcaller yang tidak merasakan efek jera atas perbutan yang dilakukan membuat korban tidak berani melaporkan, karena belum ada aturan yang menjamin kepastian hukum dari perbuatan catcalling.

Perbuatan catcalling berpotensi sebagai perbuatan yang dapat dikriminal. Dilihat dari syarat-syarat kriminalisasi yang telah dijelaskan pada bab sebelumnya, perbuatan catcalling perlu aturan untuk mendapat kepastian hukum. Adapun syarat-syarat kriminalisasi sebagai berikut:

1. Perbuatan itu tidak disukai atau dibenci oleh masyarakat, karena merugikan, atau dapat merugikan, mendatangkan korban atau dapat mendatangkan korban. Suatu perbuatan yang tidak disukai dan mengganggu kenyamanan orang yang telah menjadi objek dari suatu perbuatan tersebut. Akibat dari perbuatan tersebut menimbulkan suatu akibat dan kerugian bagi korban. Seperti perbuatan catcalling merupakan perbuatan yang meresahkan objek terutama perempuan, sudah menjadi masalah sosial di lingkungan masyakat. Dengan komentar-komentar seksual yang terlalu berlebihan serta didukung dengan tindakan seksual, gerak-gerik seksual akibat dari catcalling yang berlebihan ini berdampak pada terganggunya psikologi dan mental korban serta hak asasi manusia seperti tertera dalam Pasal 30 Undang-Undang Nomor 39 Tahun 1999 Tentang Asasi Mannusia. Sudah seharusnya

2. Biaya mengkriminalisasi seimbang dengan hasilnya yang akan dicapai, artinya cost pembuatan undang-undang, pengawasan, penegakan hukum, serta beban yang dipikul oleh korban, pelaku harus seimbang dengan situasi tertib hukum yang akan dicapai sehingga tidak terjadi tumpang 
tindih. Biaya mengkriminalisasi sebagai sanksi berupa denda harus sesuai dengan beban yang dipikul Negara.

3. Hal tersebut apakah akan makin menambah beban aparat penegak hukum yang tidak seimbang, atau nyata-nyata tidak dapat diemban oleh kemampuan yang dimilikinya. Perbuatan catcalling berpotensi tindak pidana tidak akan menjadi beban bagai aparat penegak hukum, akan tetapi jika hal ini tidak diatur dan tidak adanya kepastian hukum maka akan menambah beban bagi masyarakat yang terkena catcalling.

4. Apakah perbuatan-perbuatan itu menghambat atau mengahalangi cita-cita bangsa, sehingga bahaya bagi keseluruhan masyarakat. Perbuatan catcalling ada dan tidak akan menjadi masalah sosial apabila tidak meresahkan masyarakat terutama perempuan. Namun nyatanya perbuatan tersebut sudah berdampak buruk bagi korban, penelitian dari berbagai lembaga pun telah membuktikan sekitar 99\% perbuatan ini dialami oleh perempuan dan sudah selayaknya dikriminalisasi. Hal ini dibuktikan melalui instagram @dearcatcaller (di media tersebut korban yang terkena catcalling berbagi ceritanya).

Saat inilah perlunya kebijakan hukum terhadap perbuatan catcalling secara khusus di masa yang akan datang untuk mencapai kepastian hukum dalam menangani kasus tersebut. Untuk mencapai suatu kebijakan hukum pidana, perlu adanya perumusan moral, nilai asas serta teori yang berhubungan dengan kebijakan hukum pidana. Kebijakan hukum dilakukan harus memandang nilai-nilai yang terkandung di dalam masyarakat.

Kebijakan hukum pidana atau kebijakan penal merupakan suatu upaya dalam penanggulangan kejahatan (criminal policy). Dalam kebijakan penal mengandung pengertian:

1. Kebijakan penal diartikan sebagai upaya penanggulang suatu kejahatan dengan menggunakan sarana hukum pidana

2. Kebijkan penal ditinjau dari politik hukum pidana adanya suatu tujuan yang ingin dicapai, yakni suatu perundang-undangan dalam menanggulangi kejahatan.

3. Kebijakan penal mewujudkan suatu perundang-undangan sesuai keadaan dan masa yang akan datang ${ }^{18}$.

Ada beberapa hal mendasar yang menjadi pijakan dalam kebijakan hukum pidana ditinjau dari politik hukum yaitu:

1. Dasar pijakan berbasis ideology, menggunakan nilai-nilai yang menjadi dasar dalam berbanggsa dan bernegara.

2. Dasar pijakan politik hukum berbasis normatif, dalam hal ini berkaitan apa yang seharusnya, menilai suatu kenyataan yang ada untuk merubahnya ke arah yang benar serta baik dan buruknyan sesuatu.

18 Barda Nawawi Arief,. Op,.Cit, hlm. 30 
3. Dasar pijakan politik hukum berbasis konstitusional, konstitusi menjadi dasar untuk mengatur dan membatasi kekuasaan dan pihak lain serentak untuk menjamin hak warga Negara/rakyat.

4. Dasar pijakan politik hukum berbasis moral, perlunya moral dalam politik hukum untuk mencapai suatu tujuan. Suatu kebijakan lahir dari lembaga-lembaga yang mempunyai tingkat kesadaran moral untuk menjamin suatu kebijakan yang bermutu dan berorientasi serta berpengaruh bagi kepentingan umum. Di dalam filsafat hukum posisi moral adalah menjadi dasar yang utama dan paling tinggi tingkatannya ${ }^{19}$.

Menurut teori moralitas, dasar dari suatu kriminalitas adalah perbuatan immoral yang diancam dengan pidana. Namun tidak semua kejahatan bersumber dari perbuatan immoral, melainkan kerugian yang timbul di dalam masyarakat. Sebenarnya immoral dan kerugian yang di timbulkan saling berhubungan. Kerugian ditimbulkan dari perbuatan immoral. Seperti perbuatan catcalling yang termasuk perbuatan immoral, mengakibatkan kerugian terhadap orang lain yang menjadi korban dari segi psikis dan mental. Catcalling yang termasuk kejahatan kesusilaan, menjadi suatu problema dalam penegakan hukumnya.

Berbagai problema dalam penegakan hukum dibidang kesusilaan masih sering terjadi. Hal ini timbul karena adanya suatu penafsiran yang berbeda antara satu dengan lain. Faktanya adalah norma-norma yang hidup dimasyarakat sering kali bergeser dari segi pemahamannya bahkan ada yang berpandangan dari aspek sosiologis. Kemudian adanya pengaruh globalisasi, sehingga membuat masyarakat selalu membandinngkan dengan nilai yang hidup di luar.

Perwujudan dari suatu kebijakan hukum terhadap perbuatan pelecehan seksual verbal (catcalling) tidaklah mudah, harus berdasarkan pertimbangan nilai-nilai tertentu. Menurut Bassiouni, tujuan-tujuan yang ingin dicapai oleh pidana pada umumnya terwujud kepentingan-kepentingan yang hidup di dalam masyarakat, mempunyai kepentingan sosial serta adanya kepentingan sosial tersebut terdapat nilai-nilai yang harus dilindungi ${ }^{20}$. Adapun kepentingan-kepentingan sosial tersebut menurut Bassiouni yaitu:

1. Memelihara ketertiban dalam masyarakat yang meliputi keamanan dan kenyamanan bagi masyarakat sekitar;

2. Adanya bentuk perlindungan bagi warga masyarakat dari kejahatan yang ada, kerugian, serta menjadi masalah sosial maupun bahayabahaya yang tidak bisa dibiarkan lagi;

3. Para pelanggar hukum harus di resosialisasikan kembali;

4. Memelihara atau mempertahankan integritas mengenai dasar tertentu terkait keadilan sosial, martabat kemanusiaan, dan keadilan individu ${ }^{21}$.

Kebijakan kriminal dalam menangani suatu kejahatan tidak lepas dari masalah nilai karena seperti dikatakan oleh Christiansen "the conception of problem crime and punishment is an assential part of the culture of any society"22. Konsep nilai dalam

\footnotetext{
19 Mufti Khakim,"Kebijakan Hukum Pidana Mengenai Pornografi dalam Undang-Undang Nomor 44 Tahun 2008", Tesis Pasca Sarjana Universitas Islam Indonesia, 2014, hlm. 45.

20 Mufti Khakim,. Op.Cit., hlm. 47.

21 Barda Nawawi Arief., Op.Cit., hlm. 36.

22 Ibid., hlm. 37.
} 
pembahasan sosiologi, psikologi serta axiology (filsafat nilai). Berawal dari norma menjadi suatu norma hukum yang pada dasarnya terdapat mengenai pemahaman tentang nilai itu sendiri. Nilai adalah suatu sesuatu yang orang pandang pantas atau tidaknya, harus dikejar, diperjuangkan, diwujudkan, dilaksanakan, dan dipertahankan, sehingga nilai yang berkaitan dengan nilai buruk haruslah ditinggalkan, dilawan dan harus dicegah seperti pelanggaran hak asasi manusia ${ }^{23}$. Dapat dilihat bahwa perbuatan catcalling telah melanggar hak asasi manusia berdasarkan nilai yang terkandung dalam kehidupan sosial dan perlu dicegah melalui kebijakan hukum untuk masa yang akan datang.

Persepsi mengenai nilai itu sendiri pun bersifat relatif dan cendrung berbedabeda, kadang dalam satu kolektif yang sama bis berbeda dalam satu kategori maslah yang melibatkan pelaku dan korban ${ }^{24}$. Bagi si pelaku hal tersebut adalah bentuk yang wajar namun tidak dengan korban dengan beranggapan bahwa hal tersebut merupakan perbuatan yang tidak pantas. Perbedaan penilaian terjadi dalam suatu perbuatan pelecehan seksual verbal (catcalling). Bagi pelaku catcalling adalah bentuk candaan biasa, tetapi bagi korban catcalling merupakan hal yang harus ditindak lanjuti dan itu mengganggu kenyamanan bagi individual dri korban tersebut.

Kebijakan hukum mengenai aturan pelecehan seksual verbal (catcalling) di masa yang akan datang memerlukan pertimbangan-pertimbangan, dari segi penjatuhan pidana seperti sanksi pidana serta ruang lingkup catcalling yang bisa diproses dalam penegakan hukumnya. Pertimbangan tersebut juga mencegah terjadinya over capacity atau penuhnya kapasitas dari suatu lembaga pemasyarakatan.

Herbert I. Packer yang menghendaki tetap dipertahankannya sanksi pidana, yang mneyatakan bahwa:

1. The criminal law sanction is indispensible, we could not now or in the foreseeable future, without is (Sanksi pidana sangatlah diperlukan, kita tidak dapat hidup sekarang maupun dimasa yang akan datang tanpa pidana). Tanpa suatu pidana sebagai ultimum remedium atau upaya akhir dalam penyelesaian suatu perkara dengan tujuan menimbulkan efek jera. Apabila suatu perbuatan yang merupakan tindak pidana, namun tidak ada tindak lanjut dari segi aturan dan penerapan sanksi maka Negara akan mengalami over criminal.

2. the criminal law sanction is the best avaible device we have for dealing with groos and immediate harms and threats of harm (sanki pidana sebagai alat atau sarana terbaik yang tersedia yang kita miliki untuk menghadapi ancaman-ancaman dari bahaya).

3. the criminal sacnction is at once prime guarantor and prime threatened of human feedom. Used providentially andhumanely, it is guarantor, used indiscriminately and coercively, it is theatener. (sanksi pidana suatu ketika merupakan pengancaman yang utama dari kebebasan manusia. Ia merupakan suatu penjamin apabila digunakan secara hemat-hemat cermat dan secara manusiawi, ia merupakan pengancamanan apabila digunakan secara sembaran gan dan secara paksa ${ }^{25}$.

23 Budiono Kusumohamidjojo, Teori Hukum Dilema Antara Hukum dan Kekuasaan, Cet.1, Penerbit Yrama Widya, Bandung, 2016, hlm. 221.

24 Ibid.,hlm. 135.

25 Marlina, Hukum Penintensier, Cet.1, PT Refika Aditama, Bandung, 2011, hlm. 31. 
Adanya penerapan sanksi dari suatu perbuatan pidana akan menjamin kepastian hukum dalam penegakan hukum di masa sekarang dan di masa yang akan datang. Untuk penerapan sanksi perbuatan catcalling inipun harus mempertimbangkan akibat yang ditimbulkan, sehingga mencegah terjadinya over kapasitas. Penerapan sanksi bagi perbuatan pelecehan seksual verbal (catcalling) harus sesuai dengan akibat ${ }^{26}$ yang ditimbulkan. Dalam perspektif hukum pidana perbuatan catcalling ini merupakan bentuk kejahatan kesusilaan, dalam perumusan dan pemberian sanksi pidana tergantung nilai-nilai yang hidup dimasyarakat ${ }^{27}$. Kemudian untuk sanksi pidana yang dijatuhkan pun merupakan upaya akhir yang harus ditempuh (ultimum remedium) dan harus ada upaya awal yang menjadi sanksi bagi perbuatan catcalling. Adanya upaya awal di luar dari kebijakan penal terhadap perbuatan catcalling ini untuk memberikan kesadaran bagi catcaller atas perbuatan yang dilakukan serta berpotensi adanya efek jera. Upaya awal ini berupa sanksi sosial, karena perbuatan catcalling dikategorikan sebagai bentuk dari perbuatan yang melanggar kesusilaan. Suatu perbutan yang melanggar kesusilaan tidak terlepas dengan sanksi sosial, mengandung nilai-nilai yang tumbuh dan berkembang di dalam masyarakat.

Sanksi sosial ini merupakan sanksi yang dijatuhkan bagi pelaku sebagai upaya untuk mengurangi perbuatan catcalling. Sanksi sosial ini bersifat publik yang artinya dapat menimbulkan efek jera bagi pelaku catcalling (catcaller). Dalam penerapan sanksi sosial bisa dilakukan dengan cara pembangunan berbasis data dalam bentuk memperlihatkan sebuah public notice, foto, poster berisikan suatu data si catcaller, menerangkan bahwa orang tersebut merupakan pelaku catcalling dalam bentuk pelecehan seksual verbal dan juga bisa dicantumkan nomor hotline jika sewaktu-waktu terjadi perbuatan catcalling. Dari sanksi sosial bentuk berbasis data bisa juga bersifat online dengan cara mempublikasikan suatu perbuatan pelaku ke media sosial. Sejak maraknya perbuatan catcalling yang sampai menjadi masalah sosial di lingkungan masyarakat, hingga menciptakan suatu media sosial instagram dearcatcaller. Instagram ini berfungsi untuk menampung masalah-masalah yang pernah menjadi korban catcalling. Maka dari itu instagram ini bisa menambah fungsi untuk mempublikasi para predator pelecehan seksual verbal (catcalling), sehingga menimbulkan efek jera tanpa upaya ultimum remedium tergantung akibat yang ditimbulkan oleh perbuatan catcalling.

Selain sanksi sosial sebagai upaya awal untuk mengantisi masalah sosial, harus ada upaya lain yaitu upaya prepentif (pencegahan/ penangkalan/ pengendalian) sebelum kejahatan terjadi. Hal ini bisa mengurangi perbuatan catcalling yang sudah menjadi masalah sosial di lingkungan masyarakat. Upaya prepentif ini merupakan suatu kebijakan non penal yang bertujuan menanggulangi kejahatan (politik kriminal). Adapun usaha-usaha non penal ini misalnya penyantunan dan pendidikan sosial dalam rangka mengembangkan tanggung jawab sosial warga masyarakat, penggarapan jiwa masyarakat melalui pendidikan moral yang diberikan, agama dan sebagainya serta adanya kegiatan patroli dan pengawasan lainnya secara kontinyu oleh polisi dan aparat

26 Teori conditio sine qua non dikemukakan oleh Von Buri, yang berpendapat bahwa: suatu perbuatan atau masalahnya haruslah dianggap sebagai "sebab" dari suatu akibat, apabila perbuatan atau masalah itu merupakan syarat dari akibat itu.

27 Asrianto Zainal, "Kejahatan Kesusilaan dan Pelecehan Seksual di Tinjau Dari Kebijakan Hukum Pidana," Jurnal Al-'adl, Vol. 7 No.1, 2014, hlm. 141. 
keamanan lainnya ${ }^{28}$. Tujuan utama dari usaha non penal yaitu memperbaiki kondisi sosial tertentu, dan kondisi individual, namun secara tidak langsung kebijakan non penal mempunyai pengaruh preventif terhadap kejahatan. Upaya kebijakan non penal ini suatu upaya penanggulangan kejahatan, maka sasaran utama adalah menangani faktor-faktor penyebab terjadinya kejahatan, sehingga selain sanksi yang dijatuhkan harus memberantas yang menjadi penyebab kejahatan tersebut semakin meningkat. Dengan demikian jika dilihat dari sudut kebijakan kriminal, keseluruhan dari usaha non penal sebenarnya mempunyai kedudukan yang sangat strategis, memegang posisi kunci yang harus diintensifkan dan diefektifkan. Upaya kebijakan

Proses penerapan aturan secara khusus perbuatan catcalling merupakan suatu upaya untuk memberikan perlindungan bagi korban catcalling. Mengenai penjatuhan sanksinya harus sesuai dengan dampak yang ditimbulkan dan lebih mengutamakan sanksi berupa denda. Namun jika catcalling sampai kepada perbuatan yang fatal seperti pemerkosaan, akan dikenakan pidana.

Kebijakan hukum mengenai perbuatan catcalling salah satu bentuk pelecehan seksual yang terjadi di ruang lingkup publik masih menjadi rancangan bagi pemerintah. Pada Rancangan Undang-Undang Kitab Undang-Undang Hukum Pidana (RUU KUHP), terdapat pasal yang mengatur mengenai pelecehan seksual di ruang lingkup publik yaitu Pasal 241 Ayat (1) yang menyatakan bahwa: "Setiap orang yang melakukan perbuatan cabul terhadap orang lain yang berbeda/sama jenis kelaminnya di depan umum dipidana dengan pidana penjara paling lama 1 (satu) tahun 6 (enam) bulan pidana denda paling banyak kategori III".

Kata cabul dalam penjelasan tersebut berarti segala bentuk perbuatan yang melanggar kesusilaan, kesopanan, serta perbuatan yang tidak senonoh. Kemudian pada Rancangan Undang-Undang Penghapusan Kekerasan Seksual (RUU PKS) yang masih menjadi pro kontra dalam penetapan aturannya. Di dalam RUU PKS terdapat suatu pasal mengatur perbuatan catcalling yang merupakan bentuk dari kekerasan seksual yaitu pelecehan seksual dalam ruang lingkup publik yaitu pada Pasal 11 Ayat (1) setiap orang dilarang melakukan kekerasan seksual. Adapun jenis kekerasan seksual Pada Ayat (2) huruf a yaitu pelecehan seksual. Sesuai dengan penjelasan Pasal 11 Ayat (3), sebagaimana yang dimaksud pada Ayat (1) peristiwa kekerasan seksual itu meliputi dalam lingkup relasi personal, rumah tangga, relasi kerja, publik dan situasi khusus. Sudah jelas bahwa pelecehan seksual diruang lingkup publik menjadi hal yang serius menimbulkan suatu kebijakan hukum yang disebabkan adanya masalah sosial. Suatu kebijakan hukum dibuat dengan memperhatikan keadaan di lingkungan sosial.

Pelecehan seksual yang dimaksud pada Pasal 11 Ayat (1) huruf a yang dijelaskan pada Pasal 12 Ayat (1) RUU PKS, kategori pelecehan sesksual adalah kekerasan seksual yang dilakukan dalam bentuk fisik, non-fisik, berhubungan dengan tubuh, hasrat yang mengandung unsur seksual, sehingga menimbulkan dampak bagi korban yang merasa terintimidasi, terhina, direndahkan bahkan, dipermalukan.

Pelecehan seksual ini bersifat delik aduan, kecuali yang dilakukan terhadap anak, dan penyandang disabilitas dan anak dengan disabilitas seperti dalam penjelasan Pasal 12 Ayat (2). Dari penjelasan pasal tersebut yang menjadi kebijakan hukum di

28 Abintoro Prakoso, Kriminologi dan Hukum Pidana Pengertian, Aliran, Teori dan Perkembangannya, Cet.2, LaksBang Pressindo, Yogyakarta, 2017, hlm. 179. 
Indonesia, membuat perbuatan catcalling bukanlah suatu perbuatan yang biasa dan merupakan suatu tindak pidana.

Sejalan dengan karakteristik dari suatu tindak pidana perbuatan catcalling, yang deliknya berupa pelanggaran hak untuk hidup damai tentram dan berdampak bagi psikologis korban serta berhubungan dengan pelecehan seksual verbal. Kegiatan penelusuran perbuatan catcalling ini bisa dilakukan melalui survei secara online maupun secara langsung. Survei secara online lebih cendrung membuat orang lain yang pernah mengalami catcalling lebih terbuka dalam menceritakan pengalamannya. Seperti di akun instagram @dearcatcaller. Penelusuran bisa bekerja sama dengan Komnas Perempuan dalam survei ini.

Survei yang dilakukan untuk mengukur sebarapa banyak perbuatan catcalling telah terjadi di ruang publik menjadi suatu permasalahan global yang memerlukan kebijakan pemerintah di masa yang akan datang. Pengungkapan perkara perbuatan catcalling memerlukan tahap yang lebih khusus terhadap korban. Karena perbuatan catcalling ini termasuk delik aduan, korban yang merasakan akibat dari perbuatan itu. Pertanggungjawaban untuk perbuatan catcalling harus melihat dari segi sifat melawan hukum dan kesalahannya. Sifat melawan hukum dan kesalahan, dalam hukum pidana khususnya KUHP menganut teori monitis yang menyatakan sifat melawan hukum (wederrectelijkheid) dan kesalahan (schuld) merupakan unsur dari tindak pidana (strafbaarfeit) ${ }^{29}$.

Teori monitis, memandang suatu pertanggungjawaban pidana dilihat dari terpenuhinya rumusan tindak pidana yang terdiri dari sikap batin pembuat dan sifat melawan hukumnya pembuat ${ }^{30}$. Perbuatan catcalling kini bukanlah hal yang wajar dikalangan masyarakat, namun merupakan permasalahan global yang perlu penerapan hukum di masa yang akan datang. Dengan demikian kebijakan hukum dari perbuatan pelecehan seksual verbal (catcalling) di masa yang akan datang harus berdasarkan moral, nilai yang hidup dimasyarakat. Mengenai dampak yang ditimbulkan, serta pengaruh terhadap lingkungan masyarakat. Dalam penerapan aturan serta penegakan hukum berupa sanksi harus berdasarkan pada asas-asas dan teori dalam hukum pidana.

\section{SIMPULAN}

Perbuatan pelecehan seksual verbal (catcalling) bukanlah suatu hal yang wajar, namum merupakan suatu permasalahan global yang merugikan orang lain. Perbuatan catcalling merupakan suatu tindak pidana yang terjadi di ruang publik, seperti di jalan, pasar, angkutan umum, dan lain-lain. Orang yang pernah mengalami catcalling merasa tidak aman, tentram, damai ketika berada di luar rumah. Dampak dari perbuatan catcalling ini menimbulkan gangguan psikologis, mental seseorang. Menurut perspektif hukum pidana, perbuatan catcalling merupakan perbuatan pelecehan verbal berkaitan dengan tindak pidana yang melanggar kesusilaan. Ada pun pasal-pasal yang bisa digunakan dalam menangani perkara catcalling ini yaitu, Pasal 281 Ayat (1) KUHP,

29 Ramli Atmasasmita, Didik Endro Purwoleksono, dan Nur basuki Minarno, "Tindak Pidana \& Pertanggungjawaban Pidana Tinjauan Kritis Melalui Konsistensi antara Asa, Teori, dan Penerapannya", Cet.2, Kencana, Jakarta, 2018, hlm. 2.

30 Ibid.,hlm. 5. 
Pasal 8, Pasal 9, Pasal 34, Pasal 35 Undang-Undang Nomor 44 Tahun 2008 Tentang Pornografi.

Kemudian pengaturan perbuatan pelecehan seksual verbal (catcalling) dalam perspektif hukum pidana di masa yang akan datang, memerlukan kajian mengenai moral, nilai asas-asas, serta teori yang berkaitan dengan kebijakan hukum pidana. Dikaitkan dengan Pasal 241 RUU KUHP, Pasal 11 dan Pasal 12 RUU KPS. Aturan tersebut menjadi kebijakan hukum konstituendum bagi Indonesia. Untuk mengkriminalisasi suatu perbuatan catcalling harus perlu memperhatikan syaratsyarat kriminalisasi yaitu, apakah perbuatan tersebut tidak disukai dan dibenci merugikan korban, apakah biaya mengkriminalisasi seimbang dengan hasil yang akan dicapai, apakah akan makin menambah beban aparat penegak hukum, dan apakah perbuatan tersebut menghambat cita-cita bangsa sehingga membahayakan bagi masyarakat.

\section{DAFTAR PUSTAKA}

\section{Dokumen Hukum}

Republik Indonesia, Undang-Undang Nomor 1 Tahun 1946 Tentang Kitab UndangUndang Hukum Pidana

Republik Indonesia. Undang-Undang Tentang Pornografi. Nomor 44 Tahun 2008. UU Nomor 44 Tahun 2008. TLNRI Nomor 4928.

Republik Indonesia. Undang-Undang Tentang Perubahan atas Undang Undang Nomor 13 Tahun 2006TentangPerlindungan Saksi dan Korban. UU Nomor 31 Tahun 2014.LNRI Tahun 2006 Nomor 4635, TLNRI Nomor 5602.

\section{Buku}

Andi Hamzah. Asas-Asas Hukum Pidana (Edisi Revisi). Cetakan Keempat. Rineka Cipta, Jakarta, 2010.

Abdul Wahid, dan Muhammad Irfan. Perlindungan Terhadap Korban Kekerasan Seksual Advokasi Atas Hak Asasi Perempuan. Cetakan Kesatu. PT Refika Aditama, Bandung, 2001.

Barda Nawawi Arif. Masalah Penegakan Hukum dan Kebijakan hukum Pidana dalam Penanggulangan Kejahatan. Kencana Prenedia Media Group, Jakarta, 2007.

Bunga Rampai Kebijakan Hukum Pidana Perkembangan Penyusunan Konsep KUHP Baru, Prenadanedia Group, Semarang, 2014 Bunga Rampai Kebijakan Hukum Pidana Perkembangan Penyusunan Konsep KUHP Baru, Prenadanedia Group, Semarang, 2014.

Budiono Kusumohamidjojo. Teori Hukum Dilema Antara Hukum dan Kekuasaan. Cet Pertama. Penerbit Yrama Widya, Bandung, 2016.

Eddy O.S.Hiariej. Prinsip-Prinsip Hukum Pidana Edisi Revisi. Cahaya Atma Pustaka, 2014. 
Eli Nur Hayati, Panduan untuk Pendamping Perempuan Korban Kekerasan: Konseling Berwawasan Gender, Rifka Annisa dan Pustaka Pelajar, Yogyakarta, 2000.

Hadiati Moerti Soeraso. Kekerasan Dalam Rumah Tangga Dalam Perspektif YuridisViktimologis. Cetakan Kesatu. Edisi Kesatu, Sinar Grafika, Jakarta, 2010.

Marlina, Hukum Penintensier, Cet Pertama. PT Refika Aditama, Bandung, 2011.

Moeljanto. Asas-Asas Hukum Pidana. Cetakan Kedelapan. Rineka Cipta, Jakarta, 2008.

Moerti Hardiati Soeroso. Kekerasan Dalam Rumah Tangga Dalam Perspektif YuridisViktimologis. Sinar Grafika, Jakarta, 2010.

Mulyati Pawennei, dan Rahmanuddim Tomaili. Hukum Pidana. Mitra Wacana Media, Jakarta, 2015.

P.A.F Lamintang, dan Lamintang Theo. Delik-Delik Khusus KejahatanMelanggar Norma Kesusilaan dan Norma Kesopanan. Cetakan Kedua. Edisi Kedua. Sinar Grafika, Jakarta, 2011.

Peter Mahmud Marzuki. Penelitian Hukum (Edisi Revisi). Cetakan Kesembilan. Prenada Media Group, Jakarta, 2014.

Ramli Atmasasmita, dkk. Tindak Pidana \& Pertanggungjawaban Pidana Tinjauan Kritis Melalui Konsistensi antara Asa, Teori, dan Penerapannya. Cet Kedua. Kencana, Jakarta, 2018.

Teguh Prasetyo. Hukum Pidana Edisi Revisi. Ed Pertama. Cet kedelapan. PT. RajaGrafindo Persada, Depok, 2017.

Zainudin Ali. Metode Penelitian Hukum.Cetakan Kelima. Edisi Kedua Sinar Grafika. Jakarta, 2014.

\section{Jurnal/Makalah Ilmiah}

Andi Najemi, Pahlefi, " IbM Kelompok Pkk Desa Pematang Pulai dan Kel. Sengeti Tentang Hukum Gender Tentang Mengantisipasi KDRT, Jurnal Pengabdian Pada Masyarakat, Vol. 30 No. 1, 2015.

Asrianto Zainal, " Kejahatan Kesusilaan dan Pelecehan Seksual ditinjau Dari Kebijakan Hukum Pidana, Vol. 7 No.1, 2014.

Asrianto Zainal, "Kejahatan Kesusilaan dan Pelecehan Seksual di Tinjau Dari Kebijakan Hukum Pidana", Jurnal Al-'adl, Vol. 7 No.1, 2014.

Colleen 0'Leary, "Catcalling As a "double Eged Sword": Midwestern Women, Their Experiences, and the Implications of Men's Catcalling Behaviors, (Illinois State University, 2016).

Dewi, Ida Ayu Adnyaswari. "Catcalling: candaan, Pujian atau Pelecehan Seksual”, Acta Comitas Jurnal Hukum Kenotariatan, Vol. 4 No. 2, Fakultas Hukum Udayana, Bali, 2019. 
Eka Ayuningtyas,dkk, "Konsep Pencabulan Verbal dan Non Verbal dalam Hukum Pidana." Jurnal Education and Development Institut Pendidikan Tapanuli Selatan, Vol. 7 No. 3, 2019.

Fiana Dwiyanti, "Pelecehan Seksual Pada Perempuan di Tempat Kerja (Studi Kasus Kantor Satpol PP Provinsi DKI Jakarta)", Jurnal Kriminologi Indonesia, Vol. 10 No. 1, 2014.

Joy Gloria dkk."Perancangan Kampanye osial "JAGOAN", (Program Studi Desain Komunikasi Visual,Fakultas Seni dan Desain Universitan Kristen Petra).

Marthen H. Toella, Kriminalisasi Ditinjau Dari Perspektif Teori Hukum Pidana (Criminal Law Teory), Refleksi Hukum, Vol. 8 No. 2, 2014.

Mufti Khakim, Kebijakan Hukum Pidana Mengenai Pornografi dalam Undang-Undang Nomor 44 Tahun 2008,Tesis Pasca Sarjana Universitas Islam Indonesia, 2014.

Sumera, Marcheyla. "Perbuatan Kekerasan/ Pelecehan Seksual Terhadap Perempuan, Lex et Societatis, Vol. 1 No. 2, 2013.

\section{Website}

Putri Widia Saraswati, "Catcalling: Ketika Para Kucing Kurang Kerjaan menggodamu", dalam http://lakilakibaru.or.id/catcalling/ diakses pada 8 Desember 2019 Jam 19:18 